\title{
POLITICAL
}

INFLUENCE

BEHAVIOR AND

CAREER SuCCEsS

Working Paper 92-07

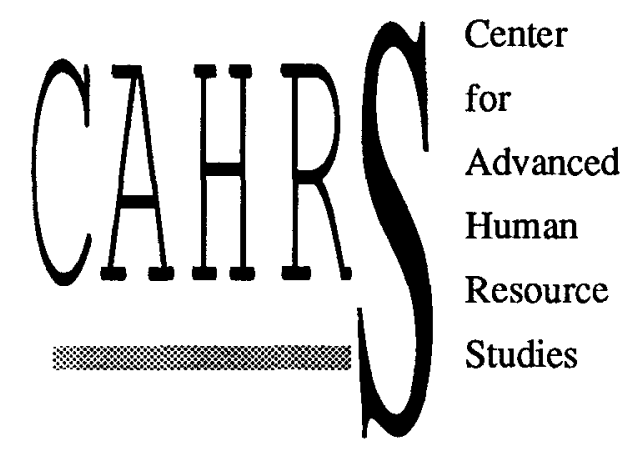

Timothy Judge and Robert D. Bretz, Jr. 


\title{
POLITICAL INFLUENCE BEHAVIOR AND CAREER SUCCESS
}

\author{
TIMOTHY A. JUDGE \\ Center for Advanced Human Resource Studies \\ New York State School of Industrial and Labor Relations \\ Cornell University \\ Ithaca, New York 14853-3901 \\ (607) $255-2740$ \\ ROBERT D. BRETZ, JR. \\ Center for Advanced Human Resource Studies \\ New York State School of Industrial and Labor Relations \\ Cornell University \\ Ithaca, New York 14853-3901 \\ (607) $255-2273$
}




\section{POLITICAL INFLUENCE BEHAVIOR AND CAREER SUCCESS}

In a recent review of the literature on politics and influence behavior in personnel/human resource management, Ferris and Judge (1991) noted that no studies had directly investigated the relationship between influence behavior and overall career success. In the present study the effect of political influence behavior on career success was investigated. Drawing from past research on influence behavior and relevant theory from social psychology, the effect of political influence behavior on career success was hypothesized to depend on the type of influence tactic employed. Support was found for the effect of political influence behavior in predicting career success, and for the differential effectiveness of influence behaviors. Implications of the results for the study of careers and career management processes are discussed. 
Past research from the careers literature has identified a number of influences on career success. These influences broadly can be classified as individual or organizational in nature (Ferris \& Judge, 1991). Some of the more prominent organizational determinants of career success identified by past research include: socialization (Feldman, 1981; Louis, 1980; Reichers, 1987; Wanous, Reichers, \& Malik, 1984), mentoring (Dreher \& Ash, 1990; Hunt \& Michael, 1983; Kram, 1983; Whitely, Dougherty, \& Dreher, 1991), type of position (Whitely et al., 1991), early career challenge (Kaufman, 1974), and career systems (London \& Stumpf, 1982). Similarly, a number of individual-level influences have been identified by past research, including cognitive ability (Dreher \& Bretz, 1991), motivational variables such as hours worked (Whitely et al., 1991), human capital variables such as education, experience, and career interruptions (Hall \& Hall, 1979; Mills, 1985; Pfeffer, 1977; Whitely et al., 1991), work/family variables such as spousal and familial demands (Cook, 1987; Greenhaus \& Beutell, 1985), and demographic influences such as gender, marital status, and socioeconomic status (Dipboye, 1986; Dreher, Dougherty, \& Whitely, 1985; Pfeffer, 1977; Powell, 1988).

Although this research has contributed a great deal to understanding of career success (Howard \& Bray, 1988), several authors have argued that past research has been limited by its focus on ability, achievement, and organizational characteristics (Pfeffer, 1989; Whitely et al., 1991). Recently, Pfeffer (1989) suggested that a political focus may be an important, yet overlooked, perspective in understanding career success. Ferris and Judge (1991) reviewed research that addressed the role of political influence behavior in predicting career success. While they noted that a handful of studies investigated the effect of influence behavior on salary progression, no research has examined the relationship between influence behavior and overall career progress. In response, they issued a call for research investigating the effect of influence behavior on career success. 
The purpose of the present study is to examine the effect of political influence behavior on career success. Based on theory and past research, different types of influence tactics are hypothesized to differentially effect career success. In order to properly interpret the effects of the influence variables, other influences on career progress, developed from past research, also were considered in predicting career success. The results hold the promise of providing the first direct support for the role of influence behavior in predicting career success.

\section{PAST RESEARCH AND RELEVANT THEORY}

\section{Past Research on Influence Behavior}

Influence behavior has been shown to significantly effect many human resources outcomes. Past research has shown that influence behavior affects selection outcomes (Baron, 1989; Beehr \& Gilmore, 1982; Dipboye \& Wiley, 1977; Gilmore \& Ferris, 1989; Tullar, 1989). Subordinate influence behavior also has been found to affect performance ratings issued by supervisors (Ferris, Judge, Rowland, \& Fitzgibbons, 1991; Kipnis \& Schmidt, 1988; Wayne \& Ferris, 1990; Wayne \& Kacmar, 1991). Moreover, the use of influence behavior in obtaining pay increases also has found general support (Bartol \& Martin, 1988, 1990; Dreher, Dougherty, \& Whitely, 1988; Freedman, 1978; Gould \& Penley, 1984; Kipnis \& Schmidt, 1988; Martin, 1987).

Salary growth can be seen as one dimension of career success, since pay increases as one's career progresses, and tends to be one of the more salient criteria against which individuals evaluate their careers (Gerhart \& Milkovich, 1989, in press; Markham, Harlan, \& Hackett, 1987). However, salary growth is not the only relevant indicator of career success. Number of promotions and job level attained are other important aspects of career progression. While Ferris and Judge's (1991) review identified a substantial body of research addressing how influence behavior affects selection, performance evaluation, and compensation decisions, no research has examined the effect of influence behavior on overall 
career success. Since several authors have suggested that promotion systems are often political in nature (Feldman \& Klich, 1991; Ferris, Russ, \& Fandt, 1989; Heisler \& Gemmill, 1978; Markham et al., 1987), research that addresses this void in the literature should prove important.

In order to understand how influence behavior affects career success, it is important to understand the social psychological processes underlying the motives behind such behaviors. A number of researchers have proposed taxonomies of influence tactics (Jones \& Pittman, 1982; Kipnis, Schmidt, \& Wilkinson, 1980; Tedeschi \& Melburg, 1984; Wayne \& Ferris, 1990). These taxonomies are based on the assumptions that (1) different motives underlie specific tactics, and (2) not all tactics are equally effective for achieving desired outcomes. The basic motives underlying influence tactics can be classified as either ingratiation or self-promotion (Ferris \& Judge, 1991). Research has suggested that selfpromotion types of tactics are more successful than ingratiating types of tactics in the employment interview (Dipboye \& Wiley, 1977; Kacmar, Delery, \& Ferris, 1990; Tullar, 1989). Conversely, in the area of performance evaluation, subordinate use of ingratiation tactics appear to lead to positive supervisor ratings of subordinate performance while use of self-promotion tactics appear to lead to lower evaluations (Ferris et al., 1991; Wayne \& Ferris, 1990). Work by Kipnis and Schmidt (1988) and Gould and Penley (1984) also demonstrated the differing effectiveness of influence tactics. Unfortunately, since there have been no direct attempts to investigate the effect of influence behaviors on career success, the differential effect of specific tactics on career progress is unknown.

\section{Theoretical Underpinnings}

Because influence behavior is essentially comprised of ingratiation and self-promotion (Ferris \& Judge, 1991), it is important to distinguish the differing motivational processes underlying each class of behavior. Ferris et al. (1991) have noted that early research tended to confound ingratiation and self-promotion, even though they are clearly distinct behaviors 
with potentially different consequences (Godfrey, Jones, \& Lord, 1986). Both of these processes have a rich history of research from the social psychology literature. This theory and research should be informative with regard to the effect of these behaviors on career success.

Jones (1964) described ingratiation as a "class of strategic behaviors illicitly designed to influence a particular other ... concerning the attractiveness of one's personal qualities" (p. 11). Clearly, attempting to appear likable lies at the core of ingratiating behaviors (Ralston \& Elsass, 1989; Regan, Straus, \& Fazio, 1974; Wortman \& Linsenmeier, 1977). One central aspect of ingratiation is other enhancement, or flattery (Jones, 1964). Again, the apparent motive of such behaviors is to increasing liking (Ralston, 1985). In fact, Heider's (1958) balance theory predicts that liking is reciprocated. That is, if individual A believes individual B likes him or her, individual A will be motivated to like individual B (Ralston \& Elsass, 1989). Considerable research from social psychology supports the fact that individuals like those who like them (Byrne, 1971; Clore \& Byrne, 1974; Pandey \& Kakker, 1982). Another major class of ingratiating behaviors is opinion conformity. Tactics such as agreeing with supervisor opinions manifest opinion conformity. Again, increasing liking may be the motivation behind such behaviors, since the well known similarity-attraction paradigm (Byrne, 1971) suggests that opinion conformity may increase perceived similarity, which in turn leads to attraction or liking (Byrne \& Griffit, 1966).

Attempts to increase perceived competence, or self-promotion, also has been a subject of theory and research in the social psychology literature. The self-serving bias refers to the tendency for individuals to attribute successful outcomes to themselves and unsuccessful outcomes to external factors (Arkin, Gleason, \& Johnston, 1976; Carver, DeGregorio, \& Gillis, 1980; Miller \& Ross, 1975; Riess, Rosenfeld, Melburg \& Tedeschi, 1981; Sicoly \& Ross, 1977). By making excuses for negative events (Snyder, Higgins, \& Stucky, 1983) and taking or enhancing credit for positive events (Gioia, 1989), individuals 
are actively promoting the assessment of their qualifications, merit, or performance (Arkin \& Sheppard, 1989).

How might the self-serving bias operate to achieve the individual's objectives? One possible explanation derives from cognitive processing models. When social perceivers (e.g., supervisors or interviewers) encode information about individuals, they search for explanations underlying the events they have observed (Crocker, 1981). Since the social perceiver often encodes and stores information in evaluative form (Motowidlo, 1986), explanations for behavior, as perceived by the evaluator, become critical in how behavioral information is recalled. Thus, if an individual can cause the social perceiver to attribute positive events to the individual and attribute negative events to factors beyond the individual's control, higher performance evaluations, promotability ratings, or pay increases may result (Ferris et al., 1991).

Gioia (1989) suggested that the self-serving bias may be particularly relevant regarding self-promotion because individuals process their own behavioral information. Because the self-serving bias effects the manner in which information is stored in memory (Gioia, 1989; Zerbe \& Paulhus, 1987 ), it may subconsciously lead individuals to credit themselves with positive outcomes and blame external factors for failures, as well as cause employees to subconsciously engage in self-promotion to provide interviewers or supervisors with the most positive information about themselves. Regardless of which (or both) information processing explanations of self-promotion are correct, these cognitive approaches would suggest that self-promotion may be instrumental in achieving desired outcomes.

On the other hand, it is possible that self-promotion, like ingratiation, influences liking. Several authors have developed models of political influence where influence behavior affects outcomes primarily through affect (Ferris \& Judge, 1991; Ferris et al., 1991; Villanova \& Bernardin, 1989; Wayne \& Ferris, 1990). The effect of affect or liking on personnel/human resource management outcomes is consistent with social psychological 
explanations of behavior, as positive affect has been shown to increase benevolence and generosity toward others (Berkowitz, 1972; Isen, 1970; Isen \& Levin, 1972). If influence behaviors only affect outcomes through their effect on liking, attempts by individuals to promote themselves would only be effective in obtaining these outcomes if liking increased. Some research suggests self-promotion tactics lead to lower affect, perhaps because individuals tend to be threatened by those who actively promote their self-image (Ferris et. al., 1991). If self-promotion does lead the decision-maker to like the individual less, selfpromotion should lead to lower career success. Thus, two social psychological explanations make apparently contradictory predictions regarding the results of self-promotion tactics. Which of these predictions is correct, whether self-promotion leads to higher career success due to the way information is processed, or lower career success due to decreased liking, depends on whether influence tactics cause success only through their effect on decisionmaker liking of the individual.

\section{HYPOTHESES}

To understand the determinants of career success, one must view success as encompassing intrinsic as well as extrinsic dimensions (Bell \& Staw, 1989; London \& Stumpf, 1982). While success typically has been construed as consisting of extrinsic factors such as pay, promotions, and status, intrinsic outcomes such as job and life satisfaction may be at least as important (Bartolome \& Evans, 1980; Bray \& Howard, 1980; Vaillant, 1977). For example, if an individual has achieved a high-level position and a number of promotions throughout their career, and earns a high salary, yet is dissatisfied with his or her job and life in general, would the person or an observer define that as success? Extrinsic and intrinsic success are different, and it is possible that a person may achieve one form of success at the expense of the other. For example, spending time with one's family and engaging in leisure activities may increase life satisfaction, chatting with co-workers while at work may increase job satisfaction, yet these behaviors may decrease extrinsic success. Past 
research has demonstrated that intrinsic and extrinsic success are positively but moderately related (Bray \& Howard, 1980; Vaillant, 1977). Accordingly, factors that increase (or decrease) extrinsic career success also would be expected to increase (or decrease) intrinsic success. Thus, intrinsic and extrinsic success are expected to positively covary, but the expected moderate correlation suggests that they are distinct constructs. Therefore, it is most appropriate to consider career success as consisting of both extrinsic and intrinsic dimensions.

Because past research has suggested that the use of influence behaviors is motivated by either ingratiation or self-promotion (Ferris \& Judge, 1991), conceptualizations of specific influence behaviors should reflect these motivations. Recently, Wayne and Ferris (1990) developed a trichotomous classification of influence behaviors that manifests these motivations. Job-focused tactics are oriented toward the job, and include enhancements and self-promoting actions intended to make one appear more competent at one's job. Thus, the motivation behind the use of job-focused tactics is self-promotion (Ferris et. al., 1991). Alternatively, supervisor-focused tactics are directed at the supervisor, and are intended to increase the supervisor's affect toward the subordinate (Wayne \& Ferris, 1990). These clearly are ingratiation attempts (Ferris et al., 1991). Finally, self-focused tactics are intended to create the impression the individual is a polite or nice person (Wayne \& Ferris, 1990). The motivation behind self-focused tactics is less clear. In fact, analyses by Ferris et al. (1991) suggested that self-focused tactics demonstrated poor psychometric properties and weak discriminant validity from the other two subscales. Based on these conceptual and empirical ambiguities, they did not include self-focused tactics in their analyses.

As indicated earlier, a critical issue in evaluating how particular influence strategies affect career success rests on whether they influence behavior through affect. Past conceptualizations and empirical data suggest that influence behaviors indeed do operate through affect (Ferris \& Judge, 1991; Ferris et al., 1991; Villanova \& Bernardin, 1989; 
Wayne \& Ferris, 1990). If tactics do influence affect, they can be expected to influence career progression because affect has been related to performance evaluation decisions (Ferris et al., 1991; Ross \& Ferris, 1981; Wayne \& Ferris, 1990). Since performance ratings often are the most heavily weighted criteria in promotion decisions (Campbell, Dunnette, Lawler, \& Weick, 1970; London \& Stumpf, 1983; Markham et al., 1987), influence tactics which increase or decrease liking will likely affect career success. Therefore, ingratiation should be effective in obtaining career success because such tactics have been found to increase liking. Conversely, self-promotion can be expected to lead to lower career success because such tactics decrease liking (Ferris et al., 1991). The assumption underlying these hypotheses is that influence behaviors affect career success through their effect on liking, which seems to be well-founded (Ferris \& Judge, 1991; Ferris et al., 1991; Villanova \& Bernardin, 1989; Wayne \& Ferris, 1990).

Based on the above arguments, and the earlier arguments that particular tactics should affect intrinsic and extrinsic success similarly, the following are hypothesized:

1a: Job-focused influence tactics will negatively affect extrinsic career success.

1b: Job-focused influence tactics will negatively affect intrinsic career success.

2a: Supervisor-focused influence tactics will positively affect extrinsic career success.

2b: Supervisor-focused influence tactics will positively affect intrinsic career success.

In order to insure that relevant influences on career progression were not omitted, which would undermine our ability to accurately test the hypotheses, an extensive network of control variables were derived. The selection of control variables was based primarily on Whitely et al.'s (1991) classification which identified human capital, job and organizational, motivational, and demographic influences on career progression. The human capital variables used in the current investigation included education (doctorate, masters, or 
undergraduate degree), type of secondary school attended (public or private), work experience (and the square of work experience since success should increase at a decreasing rate with tenure), occurrence of career interruptions, and grade point average. The job and organization variables used included employer size, access to a mentor, type of position (line or staff), and industry in which the respondent was employed (defined by single digit Standard Industry Codes). The motivational variables used included hours worked per week, and hours per week devoted to non-work factors (dependent care and household responsibilities). The demographic variables included gender, marital status, socioeconomic status, and the university the individual attended.

Although not subject to formal hypotheses, we did have expectations regarding the direction of influence of these variables. Specifically, we expected that employer size, masters degree (as compared to individuals with undergraduate degrees), mentoring received, job tenure, hours worked per week, line position, grade point average, socioeconomic status (because those from high socioeconomic backgrounds often have "connections" which afford greater job opportunities), being married, and being male, would positively predict career success. On the other hand, we expected that dependent responsibilities, household responsibilities, public secondary school, job tenure squared (because success should increase at a decreasing rate over time), career interruptions, and those with a doctorate degree (since generally those with a Ph.D. work in academic jobs and can only be promoted to two levels above entry level) would negatively predict career success.

\section{METHODS}

\section{Subjects and Procedure}

A survey assessing influence behaviors, career success and factors affecting career success was mailed to past graduates of two large industrial relations programs. The sample included all 1980 through 1986 graduates $(\underline{n}=1,561)$ from the industrial and labor relations 
school of a large Northeastern university. In addition, in order to introduce more diversity into the sample, all 651 past graduates from the industrial relations program at a large Midwestern university were surveyed. Mailing lists were provided by the school's placement and alumni relations directors. Respondents were promised a summary of the results upon return of a completed survey in a self-addressed, stamped envelope. Confidentiality of individuals' responses also was assured. Of the 2,212 surveys that were mailed, 23 were returned as undeliverable. From the Northeastern sample, 572 surveys were returned (37\%). From the Midwestern sample, 301 surveys were returned (46\%). Overall, 873 of the 2,189 deliverable surveys were returned (40\%). These response rates compare favorably with past survey research (Dillman, 1978).

Average age of the respondents was 34.8 years. Sixty-six percent of the respondents were married. Sixty-three percent of respondents were male. Seventy-four percent of respondents reported being from middle class or upper middle class backgrounds. Twentythree percent of respondents reported having experienced a significant interruption in their careers. The average respondent worked 49.6 hours per week, spent 8.7 hours performing household chores, and 5 hours per week caring for dependents. Average tenure in respondents' current job was 4 years. Average salary of respondents was $\$ 66,422$ per year. The typical respondent was working in a job 4.2 levels above entry level. The average number of promotions the respondent had received was 3.4, with an average of 1.7 of those with their current employer. Fifty-eight percent of respondents reported being at least moderately satisfied with their job; $82 \%$ reported being at least slightly satisfied with their lives in general.

\section{Measures}

Career success. Extrinsic career progress was measured by four variables. Salary, job level (defined as number of positions above entry level), number of promotions with current employer, and number of promotions in career except those with the current 
employer, were used as measures of extrinsic career success. The four variables were standardized and summed to form an overall extrinsic factors scale.

Intrinsic career success was manifested by job satisfaction and life satisfaction. Job satisfaction was measured by a single-item measure of overall job satisfaction, the Faces Scale (Kunin, 1955). In completing the Faces Scale, the respondent checks one of six faces, arranged from sad to happy, which best expresses how satisfied one is with his/her job in general. Data by Kunin (1955), Smith, Kendall, and Hulin (1969), and Scarpello and Campbell (1983) suggested that the Faces Scale is one of the best measures of overall job satisfaction. Life satisfaction was measured by the Satisfaction with Life Scale, a 5-item measure of life satisfaction that compares favorably with other measures of life satisfaction (Diener, Emmons, Larsen, \& Griffin, 1985). The statements include (1) in most ways my life is close to ideal, (2) the conditions of my life are excellent, (3) I am satisfied with my life, (4) so far I have gotten the important things I want in life, and (5) if I could live my life over, I would change almost nothing. Respondents indicate on a 1 (strongly disagree) to 5 (strongly agree) scale their agreement with these five statements that are intended to elicit overall life satisfaction. These two scales were standardized and summed to form an overall measure of intrinsic career success.

Influence behaviors. Influence tactics were measured by the scale originally developed by Wayne and Ferris (1990) and modified by Ferris et al. (1991). The respondent is asked to indicate on a 1 (never) to 7 (always) scale how often they engaged in 19 specific behaviors during the past three months. Supervisor-focused tactics were measured by 7 items on the scale. Examples of items falling into this category include: agree with your immediate supervisor's ideas; praise your immediate supervisor on his or her accomplishments; agree with your supervisor's major opinions outwardly even when you disagree inwardly. Job-focused tactics were measured by 12 items. Example items include: make others aware of your accomplishments in your job; try to take responsibility for 
positive events even when you are not solely responsible; arrive at work early in order to look good in front of others. Because of the problems with the self-focused tactics scale documented by Ferris et al. (1991), it was not included in the analyses.

Other variables. Dependent responsibilities (number of hours per week spent caring for dependents), household responsibilities (number of hours per week spent on household chores or responsibilities), employer size (number of employees working in the respondent's organization), highest degree achieved, access to a mentor, socioeconomic status $(1=$ working class to $5=$ upper class), whether the respondent's secondary school was public or private, job tenure, hours worked per week, whether the respondent worked in a line or staff position, whether the respondent had experienced a significant career interruption, marital status, gender, grade-point average, industry the respondent worked in (coded using the Standard Industry Code classification system), and the university the respondent graduated from were measured by specific questions on the employee survey.

\section{RESULTS}

Table 1 provides means and standard deviations of variables used in the analysis for respondents from both university samples. Since a number of differences were detected between respondents from the two samples, the university the respondent attended was controlled for in the analyses. Many of these differences are probably due to the fact that past graduates from the Midwest University received their degree as far back as 1949, while past graduates surveyed from the Northeast university received their degree only as far back as 1980 .

Insert Table 1 about here

The coefficient alpha reliability estimate for the four-item measure of extrinsic success was .54. The coefficient alpha reliability estimate for the two-item (formed from 
the job satisfaction and life satisfaction scales) intrinsic career success construct was .68 . While these are relatively low, Bollen (1989) and Bollen and Lennox (1991) have pointed out the limitations of internal consistency estimates of reliability and recommended a structural equations approach. A structural equation analysis, conducted using confirmatory factor analysis (Long, 1983) in LISREL 7 (Joreskog \& Sorbom, 1989), revealed that the overall model constraining measures of intrinsic and extrinsic success to load on their respective constructs provided a good fit to the data (chi-square/degrees of freedom $=2.35$; goodness-of-fit index $=.99$; adjusted goodness-of-fit index $=.98$; root-mean-square residual $=.03$; see La Du \& Tanaka, 1989, for a review of these fit statistics). Further, 99\% of the variance in the extrinsic success construct was explained by the measures and $98 \%$ of the variance in intrinsic success construct was explained. All loadings of the measures on both constructs were relatively strong (average loading was .56) and statistically significant $(\mathrm{p}<.01)$. This indicates that the measures adequately represent the hypothesized constructs.

The reliability for the job-focused tactics scale was .78 , and the reliability for the supervisor-focused tactics scale was .74 . Confirmatory factor analysis also was conducted to test the validity of the influence behavior constructs. Items hypothesized to be measures of supervisor-focused and job-focused tactics were loaded on their respective constructs. Considering the relatively large sample size (762 listwise observations were available for this analysis), the hypothesized two-factor measurement model fit the data adequately (chisquare/degrees of freedom $=2.94$; goodness-of-fit index $=.93$; adjusted goodness-of-fit index $=.91$; root-mean-square residual $=.06$ ). Loadings of measurements on their respective constructs were relatively strong (average loading was .47 ) and statistically significant $(\mathrm{p}<.01)$.

In order to ensure that the measures of the two influence behavior constructs were sufficiently distinct, and thus valid measures of the constructs they purport to assess 
(Schwab, 1980), the discriminant validity of the two influence behavior constructs was investigated. The discriminant validity of the dimensions of influence behavior was estimated by comparing the fit of the hypothesized two-factor model to a model with one general influence behavior construct. If the measures do not have adequate discriminant validity from one another, the fit of a single-factor model will not be significantly worse than the fit of the hypothesized two-factor model. In such a case, a single factor model would do an acceptable job of describing the data, and the hypothesis of the multidimensional nature of influence behaviors would be rejected.

The fit of a single-factor model was significantly worse than the hypothesized two-factor model (increase in chi-square $=263.21$ with 2 degrees of freedom, $\mathrm{p}<.001$ ) . Further, a random ordering of the measures loading on the two dimensions also yielded a worse fit to the data than the hypothesized model (e.g., increase in chi-square $=262.58$ with no increase in degrees of freedom). Overall, this evidence suggests the two dimensions of influence behavior, as assessed, are valid; the measures converge on their respective constructs yet are relatively distinct.

Table 2 displays the correlations between variables used in the analyses. Due to space constraints the industry correlations are not reported but are available upon request. Extrinsic and intrinsic success are significantly positively related, indicating a tendency for those who have been extrinsically successful to be more satisfied with their lives and jobs. Extrinsic success also was significantly correlated with hours worked, being married, and possessing a masters degree. Intrinsic success significantly correlated with being married, the use of supervisor-focused tactics, access to a mentor, and time spent caring for dependents. Supervisor-focused and job-focused tactics were significantly positively related, indicating a tendency for individuals to use both types of behavior. The use of supervisor-focused tactics was also positively related to having a mentor, being female, and having a lower grade-point average. The use of job-focused tactics also was positively 
related to having a mentor, and negatively related to job tenure and grade-point average. Finally, family issues such as time dedicated to dependent care, being married, time dedicated to household obligations, and career interruptions tended to be interrelated. Fivehundred and thirteen surveys possessed complete data on all variables (including measures of both intrinsic and extrinsic success).

Insert Table 2 about here

Table 3 presents the regression results predicting both extrinsic career success and intrinsic career success. The results indicate that job-focused tactics significantly negatively predicted extrinsic career success. Those who used a higher degree job-focused tactics had a significantly lower degree of extrinsic success in their careers than those who used these tactics less. Conversely, supervisor-focused tactics significantly positively predicted extrinsic career success. Those who used a higher degree of supervisor-focused tactics had a significantly higher degree of extrinsic career success than those who used this tactic less. Thus, hypotheses 1a and $2 \mathrm{a}$ were supported by the results.

\section{Insert Table 3 about here}

As with extrinsic career success, job-focused tactics significantly negatively predicted intrinsic career success. Those who used job-focused tactics more often reported lower levels of satisfaction with their jobs and lives in general than those who used this tactic less. Conversely, supervisor-focused tactics significantly positively predicted intrinsic career success. Those who used supervisor-focused tactics more often reported higher levels of job and life satisfaction than those who used this tactic less. Thus, hypotheses $1 b$ and $2 b$ were 
supported by the results. It does appear that influence behavior significantly affects intrinsic and extrinsic career success, and these effects are dependent upon the type of tactic used.

Although not subject to hypotheses, several variables exerted significant influences on career success. Specifically, mentoring significantly predicted intrinsic career success but not extrinsic success, suggesting that in this sample mentoring yields more psychic than tangible benefits. Similarly, career interruptions significantly negatively predicted intrinsic but not extrinsic career success, suggesting that career interruptions may cause lower levels of satisfaction but do not necessarily hinder extrinsic success. Similarly, socioeconomic status significantly positively predicted intrinsic success but not extrinsic success. Married individuals were more successful intrinsically and extrinsically in their careers, supporting the stabilizing influence of marriage on individuals (Viscusi, 1980). Job tenure and hours worked positively predicted extrinsic career success, suggested that those who work more gain extrinsic outcomes in their careers, and, not surprisingly, extrinsic success tends to accrue to those who have "paid their dues." The quadratic of job tenure negatively predicted extrinsic success, indicating that while extrinsic outcomes do tend to come with time, the flow of such outcomes decreases over time. Finally, doctorate degree significantly negatively predicted extrinsic success. This is not surprising since most individuals with a doctorate degree work at colleges and universities, where there are few job levels, and thus few promotion opportunities. Finally, individuals working in the manufacturing industry progressed less in their career.

Because the data are cross-sectional in nature, it is possible that in addition to influence behavior affecting career success, career success affects the use of influence behaviors. Ferris and Judge (1991), for example, have noted that influence behaviors may be more likely to be used at higher levels in the organization (e.g., by people who have had a high degree of extrinsic success). This issue was anticipated in developing the survey. Because LISREL allows testing nested models, if adding a causal link to the model 
significantly improves the fit of the model, the original hypothesized causal ordering is rejected. In other words, it is possible to test whether the relationship between influence behavior and career success is nonrecursive in nature. If it is, then the interpretation of the regression results presented in Table 3 may not be valid because the mutual effects should be considered jointly. On the other hand, if adding a link from extrinsic success to influence behavior does not result in a significant improvement in fit, the interpretation of the regression results as indicating the effect of influence behavior on career success would be supported. Based on Ferris and Judge's (1991) review of the politics literature, age, spatial distance, ambiguity, seeing politics as an opportunity, seeing politics as a threat, accountability, self-monitoring, and formalization were used as instrumental variables to predict each influence behavior. Adding a link from extrinsic career success to use of supervisor-focused tactics did not result in a significant increase in fit (decrease in chi-square $=2.23$; decrease in degrees of freedom $=2 ; \underline{\mathrm{ns}}$ ), or from extrinsic success to job-focused tactics (decrease in chi-square $=4.8$; decrease in degrees of freedom $=2$; $\underline{\text { ns }}$ ). Thus, the inferences based on the regression results presented in Table 3 appear to be valid.

\section{DISCUSSION}

Research on careers traditionally has been dominated by rational models, in which organizations establish career systems and promotion strategies designed to reward the most productive employees. The considerable emphasis placed on systematic and formalized techniques such as replacement charts (Dunn, 1982; London \& Stumpf, 1982; Walker, 1980) and career paths (Dalton, Thompson, \& Price, 1977; London \& Stumpf, 1982) epitomize the rational approach. Similarly, career development has been based on a rational model. For example, the career planning literature is replete with rationalistic prescriptions of selfassessment, analysis of gaps between one's skills and abilities and those required in future positions, and then taking actions to eliminate the discrepancies (Barr, 1980; London \& Stumpf, 1982). Furthermore, human capital theories of career progress also are based on a 
rational model -- individuals are rational, mobility restrictions are minimal, and advancement accrues to those who have invested the most in their human capital.

Like theories and prescriptions regarding career success, empirical studies on the determinants of career success have followed a rational framework, where career success is assumed to be a logical function of factors such as human capital characteristics, motivational variables, and work/family influences (Whitely et al., 1991). The increased knowledge about career success that has been obtained from these studies should not be discounted. However, these results present one perspective on careers -- that what one gets out of a career is a function of what one puts into it in terms of investments in human capital and motivation.

Another approach to careers, the political perspective, recently has begun to be emphasized. A number of authors have pointed out that promotion systems are often political in nature (Ferris \& Buckley, 1990; Ferris, Russ, \& Fandt, 1989; Markham et al., 1987; Riley, 1983). Pfeffer (1989) has argued that the political perspective allows more accurate description of how career success is determined in many organizations. The political perspective presumes that by investigating how political behavior can affect careers, careers can be analyzed from a more realistic perspective, and thus better equip individuals to comprehend and cope with organizational realities (Pfeffer, 1989). In reviewing the literature, Ferris and Judge (1991) noted that none of the published work on politics and career success contained actual empirical data regarding the effect of political influence behavior on career success, and called for more research linking influence behavior to career success.

The present study sought to fill that void. The results demonstrated that political influence behavior significantly predicted both intrinsic and extrinsic career success. Furthermore, consistent with hypotheses, different tactics exerted different effects on career success. Specifically, job-focused tactics, manifesting a strategy of self-promotion, 
negatively predicted career success. Conversely, supervisor-focused tactics, manifesting a strategy of ingratiation, positively predicted career success.

These findings are consistent with earlier arguments that political influence behaviors induce career success through their effect on affect. Those strategies which raise decisionmaker's affect toward the individual tend to be successful. Those which lead to lower affect tend to be unsuccessful. Past research has suggested that self-promotion strategies lead to lower affect while ingratiation strategies lead to higher affect (Ferris \& Judge, 1991; Ferris et al., 1991). Further, supervisor affect toward the subordinate has been found to influence performance ratings the supervisor issues to subordinates (Cardy \& Dobbins, 1986; Kingstrom \& Mainstone, 1985; Ferris et al., 1991; Tsui \& Barry, 1986; Wayne \& Ferris, 1990). Since performance and promotability ratings are most often the basis for promotions and pay increases (Gerhart \& Milkovich, 1989; Markham et al., 1987), this may explain why self-promoting types of behaviors apparently hurt one's career while ingratiating types of behaviors seem to help one's career.

These results present clear implications for individual career management strategies. Those who seek to use political behavior as a means of advancing their careers should choose their weapons carefully. Use of the wrong strategy may backfire. Specifically, individuals who seek to further their careers by attempting to increase their perceived competence in the eyes of others may be less successful in their careers than those who ingratiate. This suggests that those who use political behaviors as a means of advancing their careers may be well advised to rely on ingratiation rather than self-promotion as a career strategy. In plain words, "apple polishing" seems to be a better means of getting ahead than "blowing one's own horn." The results also suggest that there is more to achieving career success than relying on rational self-assessment, deficiency diagnosis, and career paths. Models of career planning may want to consider the importance of politics in obtaining career success. It is important to note, since definitions of career success can vary 
between individuals, that the effectiveness of ingratiation and the ineffectiveness of selfpromotion was observed for both extrinsic and intrinsic success.

In addition to the practical implications for individual career management, the results also possess implications for career research. Pfeffer (1989) has argued that while a rational focus was a reasonable basis on which to conduct early research on careers, a political perspective also is needed. According to Pfeffer (1989), exclusive reliance on a rational model is limiting because the rational prescriptions for individual career success and internal staffing processes often neglect the realities of how careers are managed and positions filled. By focusing on the effect of influence behavior on individual career success, the present study supports the efficacy of the political perspective on careers; career success is more than a combination of organizational career systems and human capital characteristics. Future research seeking to understand the realities of promotion and career management in organizations should therefore take the political perspective into account.

\section{Limitations, Contributions, and Future Research}

There are several limitations of the present study that should be mentioned. The hypotheses that self-promoting influence behaviors would negatively predict career success and ingratiating influence behaviors would positively predict career success received general support from the results. However, recall that these hypotheses were based on the assumption that the influence tactics resulted in career success only through their effect on decision-maker affect toward the individual. Unfortunately, it would be infeasible in the present study to collect data from each individual's present and past supervisors regarding the supervisors' degree of affect toward the individual. While there is reason to believe that this assumption (i.e., that influence tactics only affect career outcomes through their effect on supervisor or decision-maker affect) is reasonable (Ferris \& Judge, 1991; Ferris et al., 1991; Villanova \& Bernardin, 1989; Wayne \& Ferris, 1990), it cannot be tested directly by 
our data. Future research is needed to investigate the mediating effect of supervisor or decision-maker affect toward the subordinate in the career progression process.

Another limitation of the present study is the lack of longitudinal data. Causal inferences between influence behavior and career success can best be facilitated by measuring influence behavior at one point in time and measuring career success at a later point in time. However, this data collection process would be quite difficult to accomplish, since it may take many years to achieve career success. It is probably because of these difficulties that the lack of longitudinal research in the career literature is a common theme that has been noted by others (Ferris \& Judge, 1991; Gould \& Penley, 1984; Whitely et al., 1991). In the present study an attempt was made to mitigate this concern by employing nonrecursive causal techniques. While covariance structure models do not permit proof of causality, they do support inferences of causality (Joreskog \& Sorbom, 1989). Thus, while the LISREL results suggest that the direction of causality was from influence behavior to career success, longitudinal data would increase our confidence in such an inference.

Finally, since individuals self-reported all information used in the analysis, it is possible that self-report variance biased the relations observed. However, problems with self-reporting are more severe when relating attitudinal information to other attitudinal information than when relating attitudinal data with demographic or other "objective" information (Dreher \& Ash, 1990; Podsakoff \& Organ, 1986). This suggests more caution should be exercised in interpreting the effect of influence behavior on intrinsic success than in interpreting the effect of influence behavior on extrinsic success. Furthermore, often there are no viable alternatives to self-reports for gathering information regarding many of the variables used in the study. Nevertheless, it is possible that some of the relations observed in the present study were observed due to self-report variance.

Despite these limitations, the present study may make several contributions to the study of careers in organizations. Most importantly, this is the first study to directly link 
influence behaviors to overall career success. Previous research had only proceeded to the point of relating influence behaviors to compensation; no previous study has measured overall career success. Furthermore, the distinction between extrinsic and intrinsic success also is important. We expected, and generally found, that influence behaviors had similar effects on intrinsic and extrinsic success. However, this pattern did not hold with respect to several variables in the model (e.g., mentoring, hours worked, job tenure, career interruption, socioeconomic status). This serves to reinforce the fact that while extrinsic and intrinsic outcomes go hand-in-hand for most individuals, this by no means is universally true. Each dimension of success is distinct and should be investigated separately.

Finally, the results of the present study supported our hypotheses regarding the differential effectiveness of influence behaviors. It is not simply a matter of whether political influence works or does not work -- the effectiveness of political behavior depends on the type of strategy employed. While the differential effectiveness of influence behaviors has been found in other areas of human resource management (Ferris \& Judge, 1991), it is important to note this distinction in terms of career success.

The present study suggests several potentially fruitful areas for future research. Several researchers have argued that individuals go through career stages, and that career planning and career management processes should vary depending on the stage an individual is in (Crites, 1976; London \& Stumpf, 1982). It would be interesting to investigate if the effect of influence behavior on career success depends on the career stage of the individual. Is political behavior particularly important when one is trying to establish oneself in the organization, or is influence behavior particularly important as a defensive mechanism to avoid become plateaued? Future research investigating such questions may be informative to individuals managing their careers.

Beyond the effect of influence behavior on career outcomes, it also would be interesting to examine the relationships between career processes and the use of influence 
tactics. For example, are influence tactics used to overcome perceived deficiencies in preparation or training? Does sponsorship alleviate the need (real or perceived) to engage in self-promotion and/or ingratiating behavior? Does cognitive ability moderate the degree to which influence tactics contribute to career success? Through examination of the interrelationships between individual differences, career processes, and influence behavior effectiveness, improved understanding of the role political behavior plays in careers is likely.

Another area for future research is the issue of dimensions of influence behaviors. There are a number of taxonomies of influence behavior that have been proposed (Jones \& Pittman, 1982; Kipnis, Schmidt, \& Wilkinson, 1980; Tedeschi \& Melburg, 1984; Wayne \& Ferris, 1990). It would be useful for future research to evaluate the relative validity and usefulness of these taxonomies. Schriesheim and Hinkin (1990) and Yukl and Falbe (1990) recently have examined the Kipnis et al. (1980) taxonomy. More work of this nature is called for, particularly in terms of comparing the various taxonomies.

Finally, it would useful for future research to replicate the results presented in this study using more heterogeneous samples of workers. While gathering data from two universities increases generalizability of the results, even greater generalizability could be obtained by sampling respondents from various degree programs in a number of universities.

In conclusion, the present study provided the first direct test of the effect of political influence behavior on overall career success. Drawing from past theory and research on influence behavior and careers, support was found for the effectiveness of influence behaviors in predicting career success. Distinctions were made, and supported, between two dimensions of specific influence behaviors and two facets of career success. Hopefully, these results will provide a stimulus for future research further investigating the role of influence behavior in obtaining career success. 


\section{REFERENCES}

Arkin, R.M., \& Sheppard, J.A. 1989. Self-presentation styles in organizations. In R.A. Giacalone \& P. Rosenfeld (Eds.), Applied impression management: How image making affects organizations: 125-139. Newbury Park, CA: Sage.

Arkin, R.M., Gleason, J.M., \& Johnston, S. 1976. Effects of perceived choice, expected outcome, and observed outcome on an action of the causal attributions of actors. Journal of Experimental Social Psychology, 12: $151-158$.

Baron, R.A. 1989. Impression management by applicants during employment interviews: The "too much of a good thing effect". In R.W. Eder \& G.R. Ferris (Eds.), The employment interview: Theory, research, and practice: 204-215. Newbury Park, CA: Sage Publications.

Barr, D.F. 1980. More needs analysis. Training and Development Journal, $\underline{34}$ : 70-74.

Bartol, K.M., \& Martin, D.C. 1990. When politics pays: Factors influencing managerial compensation decisions. Personnel Psychology, 43: 599-614.

Bartol, K.M., \& Martin, D.C. 1988. Influences on managerial pay allocations: A dependency perspective. Personnel Psychology, 41: 361-378.

Bartolome, F, \& Evans, P.A. 1980. Must success cost so much? Harvard Business Review, 58: 137-148.

Beehr, T.A., \& Gilmore, D.C. 1982. Applicant attractiveness as a perceived job-relevant variable in selection of management trainees. Academy of Management Journal, 25: 607-617. 
Bell, N.E., \& Staw, B.M. 1989. People as sculptors versus sculpture: The roles of personality and personal control in organizations. In M.B. Arthur, D.T. Hall, \& B.S. Lawrence (Eds.), Handbook of career theory: 232-251. Cambridge, UK: Cambridge University Press.

Berkowitz, L. 1972. Social norms, feelings, and other factors affecting helping and altruism. In L. Berkowitz (Ed.), Advances in experimental social psychology, $\underline{6}$ : 63-108. New York: Academic Press.

Bollen, K., \& Lennox, R. 1991. Conventional wisdom on measurement: A structural equation perspective. Psychological Bulletin, 110: 305-314.

Bollen, K.A. 1989. Structural equations with latent variables. New York: Wiley.

Bray, D.W., \& Howard, A. 1980. Career success and life satisfactions of middle-aged managers. In L.A. Bond \& J.C. Rosen (Eds.), Competence and coping during adulthood: 258-287. Hanover, NH: University Press of New England.

Byrne, D. 1971. The attraction paradigm. New York: Academic Press.

Byrne, D., \& Griffit, W. 1966. A developmental investigation of the law of attraction. Journal of Personality and Social Psychology, 4: 699-702.

Campbell, J.P., Dunnette, M.D., Lawler, E.E. III, \& Weick, K.E., Jr. 1970. Managerial behavior, performance, and effectiveness. New York: McGraw-Hill.

Cardy, R.L., \& Dobbins, G.H. 1986. Affect and appraisal accuracy: Liking as an integral dimension on evaluating performance. Journal of Applied Psychology, 71: 672-678.

Carver, C.S., DeGregorio, E., \& Gillis, R. 1980. Ego-defensive bias in attribution among two categories of observers. Personality and Social Psychology Bulletin, 6: $44-50$. 
Clore, G.L., \& Byrne, D. 1974. A reinforcement affect model of attraction. In L.T. Huston (Ed.), Perspectives on interpersonal attraction: 143-170. New York: Academic Press.

Cook, A.H. 1987. Work and family: Juncture and disjuncture. ILR Report, 25: 5-9.

Crites, J.O. 1976. A comprehensive model of career adjustment in early adulthood. Joumal of Vocational Behavior, 32: 105-118.

Crocker, J. 1981. Judgment of covariation by social perceivers. Psychological Bulletin, 90: 272-292.

Dalton, G.W., Thompson, P.H., \& Price, R.L. 1977. The four stages of professional careers -- A new look at performance by professionals. Organizational Dynamics, $\underline{6}$ : 17-33.

Diener, E. 1984. Subjective well-being. Psychological Bulletin, 95: 542-575.

Diener, E., Emmons, R.A., Larsen, R.J., \& Griffin, S. 1985. The satisfaction with life scale. Journal of Personality Assessment, 49: 71-75.

Dillman, D.A. 1978. Mail and telephone surveys: The total design method. New York: Wiley.

Dipboye, R.L. 1986. Problems and progress of women in management. In Working women: Past, present, and future: 118-153. Madison, WI: IRRA.

Dipboye, R.L. \& Wiley, J.W. 1977. Reactions of college recruiters to interviewee sex and self-presentation style. Joumal of Vocational Behavior, 10: 1-12.

Dreher, G.F., \& Ash, R.A. 1990. A comparative study of mentoring among men and women in managerial, professional, and technical positions. Journal of Applied Psychology, 75: 539-546.

Dreher, G.F., \& Bretz, R.D. 1990. Cognitive ability and career attainment: Moderating effects of early career success. Journal of Applied Psychology, 76: 392-397. 
Dreher, G.F., Dougherty, T.W., \& Whitely, B. 1985. Generalizability of MBA degree and socioeconomic status effects on business school graduates' salaries. Journal of Applied Psychology, 70: 769-773.

Dreher, G.F., Dougherty, T.W., \& Whitely, W. 1988. Influence tactics and salary attainment: A study of sex-based salary differentials. Paper presented at the Academy of Management, 48th Annual National Meeting, Anaheim, CA.

Dunn, B.D. 1982. The skills inventory: Second generation. Personnel, SeptemberOctober: $40-44$.

Feldman, D.C. 1981. The multiple socialization of organizational members. Academy of Management Review, 6: 309-318.

Feldman, D.C., \& Klich, N.R. 1991. Impression management and career strategies. In R.A. Giacalone \& P. Rosenfeld (Eds.), Applied impression management: How image making affects organizations: 67-80. Newbury Park, CA: Sage Publications.

Ferris, G.R., \& Buckley, M.R. 1990. Performance evaluation in high technology firms: Process and politics. In L.R. Gomez-Mejia \& M.W. Lawless (Eds.), Organizational issues in high technology management: 243-263. Greenwich, CT: JAI Press.

Ferris, G.R., \& Judge, T.A. 1991. Personnel/human resources management: A political influence perspective. Journal of Management, 17: 447-488.

Ferris, G.R., Judge, T.A., Rowland, K.M., \& Fitzgibbons, D.E. 1991. Subordinate influence and the performance evaluation process: Test of a model. Working paper no. 90-20, Center for Advanced Human Resource Studies, Cornell University. 
Ferris, G.R., Russ, G.S., \& Fandt, P.M. 1989. Politics in organizations. In R.A. Giacalone \& P. Rosenfeld (Eds.), Impression management in the organization: 143-170. Hillsdale, NJ: Lawrence Erlbaum.

Freedman, S.M. 1978. Some determinants of compensation decisions. Academy of Management Journal, 21: 379-409.

Gerhart, B.A., \& Milkovich, G.T. (1989). Salaries, salary growth, and promotions of men and women in a large, private firm. In R.T. Michael, H.I. Hartmann, \& B. O’ Farrell (Eds.), Pay equity: Empirical inquiries: 23-43. Washington: National Academy Press.

Gerhart, B.A., \& Milkovich, G.T. in press. Employee compensation: Research and practice. In M.D. Dunnette \& L.M. Hough (Eds.), Handbook of industrial and organizational psychology (2nd ed.). Palo Alto, CA: Consulting Psychological Press.

Gilmore, D.C., \& Ferris, G.R. 1989. The effects of applicant impression management tactics on interviewer judgments. Journal of Management, 15 : $557-564$.

Gioia, D.A. 1989. Self-serving bias as a self-sensemaking strategy: Explicit vs. tacit impression management. In R.A. Giacalone \& P. Rosenfeld (Eds.), Applied impression management: How image making affects organizations: 219-234. Newbury Park, CA: Sage Publications.

Godfrey, D.K., Jones, E.E., \& Lord, C.G. 1986. Self-promotion is not ingratiating. Journal of Personality and Social Psychology, 50: 106-115.

Gould, S., \& Penley, L.E. 1984. Career strategies and salary progression: A study of their relationships in a municipal bureaucracy. Organizational Behavior and Human Performance, 34: 244-265. 
Greenhaus, J.H., \& Beutell, N.J. 1985. Sources of conflict between work and family roles. Academy of Management Review, 10: 76-88.

Hall, D.T. 1976. Careers in organizations. Pacific Palisades, CA: Goodyear. Hall, F.S., \& Hall, D.T. 1979. The two-career couple. Reading, MA: Addison-Wesley.

Heisler, W.J., \& Gemmill, G.R. 1978. Executive and MBA student views of corporate promotion practices: A structural comparison. Academy of Management Journal, 21: 731-737.

Heider, F. 1958. The psychology of interpersonal relations. New York: Wiley. Howard, A., \& Bray, D.W. 1988. Managerial lives in transition: Advancing age and changing times. New York: Guilford Press.

Hunt, D.M., \& Michael, C. 1983. Mentorship: A career training and development tool. Academy of Management Review, $\underline{8}$ : 475-485.

Isen, A.M. 1970. Success, failure, attention and reactions to others. The warm glow of success. Journal of Personality and Social Psychology, 15: 294-301.

Isen, A.M., \& Levin, P.F. 1972. The effect of feeling good on helping: Cookies and kindness. Journal of Personality and Social Psychology, 21: 384-388.

Jones, E.E. 1964. Ingratiation. New York: Appleton-Century-Crofts.

Jones, E., \& Pittman, T. 1982. Toward a general theory of strategic self-presentation. In J. Suls (Ed.), Psychological perspectives on the self: 231-262. Hillsdale, NJ: Lawrence Erlbaum Associates.

Joreskog, K.G., \& Sorbom, D. 1989. LISREL 7: A guide to the program and applications. Chicago: SPSS Inc. 
Kacmar, K.M., Delery, J.E., \& Ferris, G.R. 1990. The effectiveness of the use of impression management tactics by applicants on employment interview outcomes. Paper presented at the Annual Meeting of the Southern Management Association, Orlando.

Kaufman, H.G. 1974. Relationship of early work challenge to job performance, professional contributions, and competence of engineers. Journal of Applied Psychology, 59: 377-379.

Kingstrom, P.O., \& Mainstone, L.E. 1985. An investigation of rater-ratee acquaintance and rater bias. Academy of Management Journal, 28: 641-653.

Kipnis, D., \& Schmidt, S.M. 1988. Upward influence styles: Relationship with performance evaluations, salary, and stress. Administrative Science Quarterly, 33: 528-542.

Kipnis, D., Schmidt, S.M., \& Wilkinson, I. 1980. Intraorganizational influence tactics: Explorations in getting one's way. Journal of Applied Psychology, 65: $440-452$.

Kram, K.E. 1983. Phases of the mentor relationship. Academy of Management Journal, 26: 608-625.

Kunin, T. 1955. The construction of a new type of attitude measure. Personnel Psychology, 8: 65-77.

La Du, T.J., \& Tanaka, J.S. 1989. Influence of sample size, estimation method, and model specification on goodness-of-fit assessments in structural equation models. Journal of Applied Psychology, 74: 625-635.

London, M., \& Stumpf, S.A. 1982. Managing careers. Reading, MA: Addison-Wesley. 
London, M., \& Stumpf, S.A. 1983. Effects of candidate characteristics on management promotion decisions: An experimental study. Personnel Psychology, 36: 241-259.

Long, J.S. 1983. Covariance structure models: An introduction to LISREL. Beverly Hills: Sage.

Louis, M.R. 1980. Surprise and sensemaking: What newcomers experience in entering unfamiliar organizational settings. Administrative Science Quarterly, 25: 226-251.

Markham, W.T., Harlan, S.L., \& Hackett, E.J. 1987. Promotion opportunity in organizations: Causes and consequences. In K.M. Rowland \& G.R. Ferris (Eds.), Research in personnel and human resources management: Vol. 5, 223-287. Greenwich, CT: JAI Press.

Martin, D.C. 1987. Factors influencing pay decisions: Balancing managerial vulnerabilities. Human Relations, 7: 417-430.

Miller, D.T., \& Ross, M. 1975. Self-serving biases in the attribution of causality: Fact or fiction? Psychological Bulletin, 82: 213-224.

Mills, D.Q. 1985. Seniority versus ability in promotion decisions. Industrial and Labor Relations Review, 38: 421-425.

Motowidlo, S.J. 1986. Information processing in personnel decisions. In K.M. Rowland \& G.R. Ferris (Eds.), Research in personnel and human resources management: Vol. 4, 1-44. Greenwich, CT: JAI Press.

Pandey, J., \& Kakker, S. 1982. Supervisor's affect: Attraction and positive evaluation as a function of enhancement of others. Psychological Reports, $\underline{\mathbf{5 0}}$ : 470-486.

Pfeffer, J. 1977. Effects of an MBA degree and socioeconomic origins on business school graduates' salaries. Journal of Applied Psychology, 62: 698-705. 
Pfeffer, J. 1989. A political perspective on careers: Interests, networks, and environments. In M.G. Arthur, D.T. Hall, \& B.S. Lawrence (Eds.), Handbook of career theory: $380-396$. New York: Cambridge University Press.

Podsakoff, P.M., \& Organ, D.W. 1986. Self-reports in organizational research: Problems and prospects. Journal of Management, 12: 531-544.

Powell, G. 1988. Promoting equal employment opportunity. In Women and men in management: 207-235. Newbury Park, CA: Sage.

Ralston, D.A. 1985. Employee ingratiation: The role of management. Academy of Management Review, 10: 477-487.

Ralston, D.A., \& Elsass, P.M. 1989. Ingratiation and impression management in the organization. In R.A. Giacalone \& P. Rosenfeld (Eds.), Applied impression management: How image making affects organizations: $235-249$. Newbury Park, CA: Sage Publications.

Regan, D.T., Straus, E., \& Fazio, R. 1974. Linking and the attribution process. Journal of Experimental Social Psychology, 10: 385-397.

Reichers, A.E. 1987. An interactionist perspective on newcomer socialization rates. Academy of Management Review, 12: 278-287.

Riess, M., Rosenfeld, P., Melburg, V., \& Tedeschi, J.R. 1981. Self-serving attributions: Biased private perceptions and distorted public descriptions. Journal of Personality and Social Psychology, 41: 224-231.

Riley, P. 1983. A structurationist account of political culture. Administrative Science Quarterly, 28: 414-437.

Scarpello, V., \& Campbell, J.P. 1983. Job satisfaction: Are all the parts there? Personnel Psychology, 36: 577-600. 
Schriesheim, C.A., \& Hinkin, T.R. 1990. Influence tactics used by subordinates: A theoretical and empirical analysis and refinement of the Kipnis, Schmidt, and Wilkinson subscales. Journal of Applied Psychology, 75: 246-257.

Schwab, D.P. 1980. Construct validity in organizational behavior. In B.M. Staw \& L.L. Cummings (Eds.), Research in organizational behavior: Vol. 2, 3-43. Greenwich, CT: JAI.

Sicoly, F., \& Ross, M. 1977. Facilitation of ego-biased attributions by means of self-serving observer feedback. Journal of Personality and Social Psychology, 35: $734-741$.

Smith, P.C., Kendall, L., \& Hulin, C.L. 1969. The measurement of satisfaction in work and retirement. Chicago: Rand McNally.

Snyder, C.R., Higgins, R.L., \& Stucky, R.J. 1983. Excuses: Masquerades in search of grace. New York: Wiley.

Tedeschi, J.T., \& Melburg, V. 1984. Impression management and influence in the organization. In S.B. Bacharach \& E.J. Lawler (Eds.), Research in the sociology of organizations: Vol. 3, 31-58. Greenwich, CT: JAI Press.

Tsui, A.S., \& Barry, B. 1986. Interpersonal affect and rating errors. Academy of Management Journal, 32: 402-423.

Tullar, W.L. 1989. Relational control in the employment interview. Journal of Applied Psychology, 74: 971-977.

Vaillant, G.E. 1977. Adaptation to life. Boston: Little Brown.

Villanova, P. Bernardin, H.J. 1989. Impression management in the context of performance appraisal. In R.A. Giacalone \& P. Rosenfeld (Eds.), Impression management in the organization: 299-313. Hillsdale, NJ: Lawrence Erlbaum. 
Viscusi, W.K. 1980. Sex differences in worker quitting. Review of Economics and Statistics, 62 : $388-398$.

Walker, J.W. 1980. Human resources planning. New York: McGraw-Hill.

Wanous, J.P., Reichers, A.E., \& Malik, S.D. 1984. Organizational socialization and group development: Toward an integrative perspective. Academy of Management Review, 4: 670-683.

Wayne, S.J. \& Ferris, G.R. 1990. Influence tactics, affect, and exchange quality in supervisor-subordinate interactions: A laboratory experiment and field study. Journal of Applied Psychology, 75: 487-499.

Wayne, S.J., \& Kacmar, K.M. 1991. The effects of impression management on the performance appraisal process. Organizational Behavior and Human Decision Processes, 48 : $70-88$.

Whitely, W., Dougherty, T.W., \& Dreher, G.F. 1991. The relationship of career and mentoring and socioeconomic origin to managers, and professionals, early career progress. Academy of Management Journal, $\underline{34}$ : 331-351.

Wortman, C.B., \& Linsenmeier, J.A.W. 1977. Interpersonal attraction and techniques of ingratiation in organizational settings. In B.M. Staw \& G.R. Salancik (Eds.), New directions in organizational behavior: 133-178. Chicago: St. Clair.

Yukl, G., \& Falbe, C.M. 1990. Influence tactics and objectives in upward, downward, and lateral influence attempts. Journal of Applied Psychology, 75 : $132-140$.

Zerbe, W.J., \& Paulhus, D.L. 1987. Socially desirable responding in organizational behavior: A reconception. Academy of Management Review, 12: 250-264. 
TABLE 1

Means (M) and Standard Deviations (SD) of Variables Used in Analysis Northeast $U$. Midwest U.

\begin{tabular}{|c|c|c|c|c|c|}
\hline & M & SD & M & SD & $t(\operatorname{diff})$ \\
\hline Extrinsic success & -0.11 & 1.28 & 0.06 & 1.74 & -1.35 \\
\hline Intrinsic success & -0.05 & 1.67 & 0.10 & 1.66 & $-1 \cdot 18$ \\
\hline Supervisor-focused Tactics & 35.23 & 6.57 & 33.92 & 7.10 & $2.76^{*}$ \\
\hline Job-focused Tactics & 45.09 & 7.77 & 43.03 & 7.67 & $3.57^{*}$ \\
\hline Dependent Responsibilities & 4.95 & 11.84 & 5.11 & 10.80 & -0.19 \\
\hline Masters Degree & 0.38 & 0.49 & 0.74 & 0.44 & $-11 \cdot 15^{\star}$ \\
\hline Mentoring Received & 0.46 & 0.50 & 0.44 & 0.50 & 0.78 \\
\hline Socioeconomic status & 3.07 & 0.96 & 2.70 & 1.02 & $5.29^{*}$ \\
\hline Public Secondary school & 0.84 & 0.37 & 0.84 & 0.37 & 0.06 \\
\hline Job Tenure & 2.85 & 2.89 & 6.11 & 6.83 & $-7.87^{*}$ \\
\hline Job Tenure squared & 16.48 & 73.32 & 83.86 & 176.82 & $-6 \cdot 30^{*}$ \\
\hline Hours Worked per Week & 50.08 & 8.81 & 49.12 & 8.64 & 1.52 \\
\hline Household Responsibilities & 8.68 & 8.36 & 8.72 & 6.14 & -0.08 \\
\hline Line Position & 0.33 & 0.47 & 0.32 & 0.47 & 0.20 \\
\hline Career Interruption & 0.24 & 0.43 & 0.21 & 0.41 & 1.18 \\
\hline Married & 0.63 & 0.48 & 0.72 & 0.45 & $-2.80^{*}$ \\
\hline Male & 0.55 & 0.40 & 0.79 & 0.41 & $-7.80^{*}$ \\
\hline Grade-point Average & 3.32 & 0.38 & 3.61 & 0.33 & $-11.09^{*}$ \\
\hline Doctorate Degree & 0.27 & 0.45 & 0.22 & 0.41 & 1.70 \\
\hline Employer Size & 13490 & 25015 & 11433 & 21021 & 1.26 \\
\hline
\end{tabular}

* Means were significantly different ( $p<.01$; two-tailed test). 
TABLE 2

Correlations of Variables Used in Analyses

\begin{tabular}{|c|c|c|c|c|c|c|c|c|c|c|c|c|c|c|c|c|c|c|c|c|c|}
\hline Vari & iable & 1 & 2 & 3 & 4 & 5 & 6 & 7 & 8 & 9 & 10 & 11 & 12 & 13 & 14 & 15 & 16 & 17 & 18 & 19 & $20 \quad 21$ \\
\hline 1. & Extrinsic success & -- & & & & & & & & & & & & & & & & & & & \\
\hline 2. & Intrinsic Success & 25 & -- & & & & & & & & & & & & & & & & & & \\
\hline 3. & $\begin{array}{l}\text { Supervisor-focused } \\
\text { Tactics }\end{array}$ & 01 & 12 & -- & & & & & & & & & & & & & & & & & \\
\hline 4. & Job-focused Tactics & -05 & -02 & 44 & -- & & & & & & & & & & & & & & & & \\
\hline 5. & Dependent & & & & & & & & & & & & & & & & & & & & \\
\hline & Responsibilities & 01 & 09 & 02 & 00 & -- & & & & & & & & & & & & & & & \\
\hline 9. & Socioeconomic status & -10 & 08 & 07 & 03 & -00 & 04 & -11 & 05 & -- & & & & & & & & & & & \\
\hline 10. & Public School & -00 & 02 & 00 & -00 & -05 & -00 & -03 & -04 & 04 & -- & & & & & & & & & & \\
\hline 11. & Job Tenure & 14 & 06 & -03 & -09 & 01 & -14 & 03 & -09 & -14 & 02 & -- & & & & & & & & & \\
\hline 12. & Job Tenure squared & 09 & 05 & -01 & -09 & -00 & -10 & 04 & -07 & -13 & 03 & 92 & -- & & & & & & & & \\
\hline $\begin{array}{l}13 . \\
14 .\end{array}$ & $\begin{array}{l}\text { Hours Worked Per Week } \\
\text { Household }\end{array}$ & 24 & 03 & 03 & -01 & -12 & 02 & -10 & 07 & 07 & -01 & -02 & -01 & -- & & & & & & & \\
\hline 19. & Grade-point Average & 03 & 02 & -08 & -12 & 02 & 04 & 40 & -03 & -08 & 01 & 05 & 03 & 07 & 04 & 05 & 00 & 04 & 04 & - & \\
\hline 20. & Midwest University & -05 & -04 & 11 & 12 & -01 & 04 & -35 & 02 & 18 & 00 & -32 & -26 & 05 & -00 & 01 & 04 & -10 & -25 & -35 & -- \\
\hline 21. & Doctorate Degree & -17 & -00 & -03 & -07 & -04 & -16 & -59 & -01 & 07 & -03 & 11 & 07 & 13 & -03 & 14 & -02 & 07 & 10 & 02 & $05--$ \\
\hline
\end{tabular}

Note: Decimals are omitted. Correlations greater than .10 are significant at the .01 level; correlations greater than .07 are significant at the .05 level (two-tailed test). $\underline{N}=513$. 
TABLE 3

Regression Equations Predicting Extrinsic and Intrinsic Career success

Intrinsic Success

Beta

Variable

Supervisor-focused Tactics

Job-focused Tactics

Dependent Responsibilities

Employer size

Masters Degree

Mentoring Received

socioeconomic status

Public secondary school

Job Tenure

Job Tenure squared

Hours Worked per Week

Household Responsibilities

Line Position

Career Interruption

Married

Male

Grade-point Average

Midwest University

Doctorate Degree
$.21^{* *} \quad .06$

$-.18^{* *} \quad .05$

$.07 \quad .05$

$.01 \quad .04$

$-.06 \quad .06$

$.10^{*} \quad .04$

$.08^{*} \quad .04$

$.05 \quad .04$

$.02 \quad .11$

$-.02 \quad .10$

$.04 \quad .04$

$.00 \quad .04$

$-.04 \quad .04$

$-.10^{*} \quad .04$

$.24^{* *} \quad .04$

$-.05 \quad .05$

$-.05 \quad .05$

$-.01 \quad .05$
$.04 \quad .05$
Extrinsic success Beta SE

$.14^{* *} \quad .05$

$-.21^{* \star} \quad .05$

$.04 \quad .04$

$.00 \quad .04$

$-.04 \quad .06$

$.03 \quad .04$

$-.07 \quad .04$

$.01 \quad .04$

$.31^{* *} \quad .10$

$-.22^{*} \quad .10$

$.30^{* *} \quad .04$

$-.07 \quad .04$

$-.05 \quad .04$

$-.00 \quad .04$

$.18^{* *} \quad .04$

$.03 \quad .04$

$.04 \quad .05$

$.01 \quad .05$

$-.23^{* *} \quad .05$

Table 3 continues 
Table 3 continued

Intrinsic Success

Variable

Agriculture, Mining, \&

Construction Industries

Manufacturing Industry

Transportation, Communication,

\& Utility Industries

Wholesale \& Retail

Trade Industries

Finance \& Insurance Industry

Service Industry

Public Administration Industry

$R^{2}$ (Adjusted $R^{2}$ )

$\underline{N}$
SE

$.03 \quad .04$

$.02 \quad .05$

$-.03 \quad .04$

$.03 \quad .04$

$.02 \quad .04$

$.03 \quad .05$

$-.03$

.04

$.13(.09)$

552
$.23(.20)$

Extrinsic Success

Beta

SE

$-.01 \quad .04$

$-.08^{*} \quad .04$

$.06 \quad .04$

$.02 \quad .04$

$.05 \quad .04$

$-.06 \quad .05$

$-.01 \quad .04$

524

Note: ${ }^{*} \mathrm{p}<.05 ;{ }^{* *} \mathrm{p}<.01$ (one-tailed test). Individuals in nonclassified establishments (SIC $=99$ ) or those where industry was missing served as the excluded group for the industry dummy variables. 